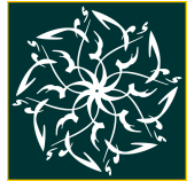

Volume 2 Nomor 1 Tahun 2020

e-ISSN: 2714-7398

\title{
TELAAH ISTINBATH HUKUM IMAM SYAFI'I TENTANG KADAR SUSUAN YANG MENGHARAMKAN PERNIKAHAN
}

\author{
Amrullah Hayatudin \\ Fakultas Syariah Universitas Islam Bandung \\ e-mail: amrullahhayatudin@gmail.com
}

Diterima: 06-06-2020 | Direvisi: 15 Juni 2020 | Disetujui: 19 Juni 2020

(C) 2020 Program Studi Ahwal Syakhshiyyah Fakultas Agama Islam Universitas Islam Malang

\begin{abstract}
Abstrak
Fiqih Munakahat mengatur bahwa hubungan persusuan menjadi sebab haramnya penikahan. Namun yang menjadi bahasan penelitian ini adalah berapa kadar susuan yang menjadikan sebab haramnya pernikahan. Dalam hal ini peneliti berusaha mengkaji pendapat salah satu ulama besar yaitu Imam Syafi'i terkait dengan Kadar susuan yang mengharamkan Pernikahan. Jenis penelitian ini merupakan penelitian kepustakaan (Library Research), yang bersifat deskriptif analisis. Hasil studi ini menunjukan hasil bahwa Imam Syafi'i dalam istinbath-nya dengan menggunakan dua metode yaitu dengan al-Quran Surat An Nisa ayat 23 dan al-Sunnah. Dalam memahami ayat 23 Surat An Nisa tersebut, Imam Syafi'i berpendapat bahwa ayat tersebut masih bisa dilakukan takhsis dengan hadits riwayat Aisyah. Sehingga Imam Syafi'i berkesimpulan bahwa kadar susuan yang menyebabkan haramnya pernikahan adalah lima kali susuan yang terputus-putus.
\end{abstract}

Kata Kunci: Kadar Susuan, Pernikahan, Istinbath Hukum

\begin{abstract}
Fiqih Munakahat maintains that tribal relations are an illegal cause of marriage. But, the problem is how much the rate of contraception can ban marriage. In this case researchers are trying to study the opinion of one of the great scholars, the Imam Syafi'i in relation to the Rate of Prohibition of Marriage. To answer this problem, researcher used the type of research in this study is library research (Library Research), with a descriptive analysis approach. And The results of this study show that Imam Syafi'i in his theory using two methods namely the Quranic Letter An Nisa 23 and al-Sunnah. In understanding Surah An Nisa 23, Imam Syafi'i argues that the ayah can still be concluded with the hadith of Aisyah. So according to the Imam Syafi'i opinion the rate of banning marriage was five times that of uninterrupted marriage.
\end{abstract}

Keywords: Rate of Birth, Marriage, Legal Te

This work is licensed under Creative Commons Attribution Non Commercial 4.0 International License Available online on: http://riset.unisma.ac.id/index.php/fai/index 
Amrullah Hayatudin

\section{A. Pendahuluan}

Perkawinan itu merupakan pelaksanaan hukum agama, yang diperintahkan Allah dan tercantum dalam Al Qur'an. Dan al qur'an memberikan aturan yang ketat terkait dengan pernikahan, suatu pernikahan menurut Islam dikatakan sah apabila memenuhi syarat, terpenuhi rukun dan tidak adanya $m \bar{a}^{\prime} n i^{\prime}$ (penghalang hukum). Dalam pernikahan ada beberapa yang bisa menjadi penghalang hukum, salah satunya diantaranya adalah hubungan persusuan. Hal ini sebagaimana Sabda Rasulullah SAW, dalam sebuah Hadits Dari Aisyah yang diriwayatkan oleh Ibnu Majah yang artinya "Berkata Rasulullah SAW: Apa yang diharamkan karena persusuan sama dengan apa yang diharamkan karena nasab" (Hayatudin 2018)

Al-Quran merupakan sumber ajaran Islam yang Allah SWT turunkan kepada nabi Muhammad SAW, melalui perantaraan Malaikat Jibril. Tidak lain adalah untuk dijadikaan sebagai pedoman hidup umat manusia, agar kelak selamat dunia maupun akhirat. Sebagai pedoman hidup, maka kandungan al Qur'an sangatlah lengkap dan komprehensif, seluruh aspek yang terkait dengan hajat hidup manusia di atur dalam Al Qur'an. Namun, dalam mengungkapkan pesan Hukumnya al Qur'an tidak secara terperinci dan sistematis, kandungan Hukum Al Qur'an kebanyakan bersifat Ijmaly atau umum. Maka, oleh sebab itu Allah SWT memberikan otoritas penuh untuk merinci dan menjelaskan keumuman kandungan-kandungan ayat al Qur'an tersebut melalui hadits-haditnya. (Habibullah 2017).

Sebagai pedoman Hidup manusia, Allah Swt mengatur terkait dengan Māni (larangan Hukum) dalam hal pernikahan. Larangan tersebut adalah terkait dengan larangan pernikahan bagi saudara sepersusuan. Terkait dengan hal ini Allah Swt mengaturnya dalam surat dala Al Qur'an tepatnya dalam QS. An Nisa ayat 23 yang artinya:

"Diharamkan atas kamu (mengawini) ibu-ibumu; anak-anakmu yang perempuan, saudara-saudaramu yang perempuan, Saudara-saudara bapakmu yang perempuan; Saudara-saudara ibumu yang perempuan; anak-anak perempuan dari saudara-saudaramu yang laki-laki; anak-anak perempuan dari saudara-saudaramu yang perempuan; ibu-ibumu yang menyusui kamu, saudara perempuan sepersusuan..."(QS. An Nissa [4]:23)

Berdasarkan Hadits dan ayat di atas, jelas dapat dipahami bahwa setiap wanita-wanita yang mempunyai hubungan nasab dan juga hubungan karena JAS: Volume 2 Nomor 1, 2020 
Telaah Istinbath Hukum Imam Syafi'i Tentang Kadar Susuan Yang Mengharamkan Pernikahan

sepersusuan haram dinikahi (Mughniyah 1996). Dan secara dzahir segala macam susuan dapat menjadikan sebab haramnya perkawinan (Hayatudin 2018). Jadi menurut dzahir ayat tersebut di atas bisa disepakati bahwa wanita-wanita yang haram dinikahi adalah; ibu atau anak perempuan, saudara perempuan atau bibi baik dari pihak bapak maupun ibu, atau keponakan perempuan (dari saudara sesusuan laki-laki maupun perempuan) karena hubungan persusuan.

Berdasarkan ayat tersebut di atas, terdapat perbedaan para ulama dalam memahami ayat tersebut. Maka, dalam penelitian ini peneliti mencoba untuk melakukan penelitian terkait istinbath hukum Imam Syafi'i dalam memahami dan mengeluarkan hukum dari ayat tersebut di atas terkait kadar susuan yang mengharamkan pernikahan. Dan yang melatar belakangi ketertarikan peneliti mengkaji Istinbath Hukum satu Imam Madzhab saja yaitu Imam Syafi'i. Karena, berdasarkan beberapa penelitian dan fakta di lapangan mayoritas umat Islam Indonesia berpaham Syafiiyah dalam berfiqh, terlihat dari Kaifiyyāt ibadah seharihari yang cenderung menggunakan Kaifiyyāt madzhab syafiyah. Dan Mazhab ini sudah begitu lama berkembang di tengah-tengah mayoritas umat Islam Indonesia.(Rohmah dan Zafi 2020), sehingga menurut pandangan peneliti ini adalah hal yang sangat menarik untuk diteliti, terutama dengan terkait dengan kadar susuan yang mengharamkan pernikahan.

Disamping hal di atas, ada hal yang cukup menarik dan penting untuk dikaji terkait dengan kadar susuan yang mengharamkan pernikahan adalah, adanya kebiasaan masyarakat Indonesia yang menyusukan anak bayinya kepada orang lain. Tanpa mereka sadari bahwa apa yang dilakukannya mempunyai akibat Hukum, salah satunya adalah akan adanya hubungan saudara sepersusuan, antara anaknya dan anak tetangga yang menyusui anaknya tersebut. Dan adanya penomena manarik dewasa ini terkait dengan maraknya bank ASI (Air Susu Ibu), meskipun pada mulanya ini berkembang di erofa dan Amerika, akibat dari tingginya wanita yang berkarir di luar rumah sehingga untu memenuhi kebutuhan ASI buat anaknya mereka membeli di Bank ASI Tersebut (Sari n.d.).

Dari pemaparan tersebut jelas di atas, menurut pandangan peneliti ini menjadi bahan kajian yang menarik untuk diteliti, di satu sisi budaya saling menyusui anak di kalangan masyarakat Indonesia masih tinggi, ditambah dengan mulai adanya Bank ASI. Di satu sisi Masyarakat kita mayoritas Muslim dan berpaham Madzhab Syafii. Jadi, fokus kajian pada penelitian ini adalah bagaimana Imam Syafi'i dalam melakukan Istinbath Hukum terkait kadar susuan yang 
Amrullah Hayatudin

mengakibatkan adanya ikatan saudara sepersusuan, yang berakibat terhadap haramnya pernikahan. Dengan adanya penelitian ini diharapkan masyarakat bisa tahu, dan akan berhati-hati dalam hal menyusukan anaknya kepada orang lain, atau membeli Air Susu Ibu (ASI) dari bank ASI.

\section{B. Metode}

Peneliti menggunakan metode dekriptif analitis, maksudnya berusaha menggambarkan konsep Istinbath Ahkam yang digunakan Imam Syafi'i terkait pendapatnya tentang kadar susuan yang mengharamkan pernikahan. Adapun analisis yang digunakan adalah analisis kualitatif, dengan jenis penelitian library research.

Penelitian ini dilakukan untuk mengetahui metode istinbath Imam Syafi'i terkait dengan kadar susuan yang mengharamkan pernikahan, dan sudah ada beberapa penelitian terkait dengan kadar susuan diantaranya adalah penelitian yang dilakukan peneliti sendiri yang diterbitkan di Jurnal Tahkim dengan judul "Istinbath Hukum Imam Malik Ibn Anas Tentang Kadar Susuan Yang Mengharamkan Pernikahan". Penelitian terdahulu menganalisis pendapat Imam Malik, sementara penelitian sekarang lebih menitik beratkan pada metode istinbathnya Imam Syafi'i.

Mengambil pendapatnya Imam Syafi'i, karena peneliti memandang bahwa pendapat Imam Syafi'i banyak digunakan oleh mayoritas umat Islam di Indonesia, sehingga peneliti memandang penelitian ini perlu dilakukan. Dan sebagai upaya pemberian ilmu pengetahuan yang lebih terkait dengan kadar susuan yang mengharapkan pernikahan.

\section{Hasil dan Pembahasan}

\section{Biografi Imam Syafi'i}

Muhammad Idris Al Syafii atau dikenal dengan sebutan Imam al-Syafi'i lahir di Gazza Palestina pada tahun 150 H/767 M, pada masa Kekhilafahan Abbasiyyah, (Ningrum 2017). Imam Syafi'i merupakan anak dari Idris ibn al-Abbas ibn Syafi'i ibn al-Saib ibn Ubaid ibn Abdul Yazid ibn Hasyim ibn al-Muthalib ibn Abdi Manaf. Jadi nama Al Syafi'i diambil dari nama Kakeknya yaitu Syafi'i, Imam Syafi'i masih keturunan Bani Quraisy baik dari jalur bapak maupun ibu. Nasab beliau dari bapak bertemu dengan nasab Nabi Muhamamad Saw dari pada Hasyim ibn al Muthalib

JAS: Volume 2 Nomor 1, 2020 
Telaah Istinbath Hukum Imam Syafi'i Tentang Kadar Susuan Yang Mengharamkan Pernikahan

ibn Abd Manaf. Sementara dari jalur ibu, karena ibu Imam al Syafi'i merupakan salah satu cucu dari saudara perempuan ibunya Ali bin Abi Thalib as. Bapak dan Ibunda Imam Syafi'i pernah tinggal di Kota Makkah dan juga Madinah, namun demi penghidupan yang lebih layak, bapak dan ibunya pergi meninggalkan Madinah menuju kota Gaza (Palestina) (Mulyosari, tt).

Terdapat beberapa versi sejarah terkait dengan kelahiran Imam Syafi'i, seperti yang sudah dijelaskan di atas ada versi yang mengatakan Imam Syafi'i lahir di Gaza, menurut versi buku sejarah yang lain menyatakan bahwa Imam Syafi'i dilahirkan di kota Asqalan, sebuah daerah yang berjarak sekitar satu hari perjalanan dari Baitul Maqdis. Dan ada versi yang lain, meriwayatkan bahwa Imam Syafi'i lahir di kota Yaman. Versi terakhir ini diriwayakan oleh Yaqut dari Imam alSyafi'i, beliau berkata bahwa Imam Syafi'i pernah berkata kepadanya: "Aku lahir di Yaman, lalu ibuku merasa khawatir jika nanti aku terlantar, maka pada usia sekitar sepuluh tahun ibuku membawa aku pindah ke kota Makkah (Hidayat 2018). Sementara, dalam semua versi sejarah tersebut dikatakan bahwa Imam Syafi'i ketika dilahirkan bapaknya sudah meninggal, jadi menurut hampir seluruh ahli sejarah Imam Syafi'i lahir dalam keadaan Yatim, (Rohidin 2004).

Dalam hal pendidikan Imam Syafi'i pernah belajar di kota Makkah, dan selama di sana beliau banyak berlajar ilmu-ilmu agama, kepada ulama-ulama besar kota Makkah, dan ilmu yang dipelajarinya meliputi ilmu fiqh dan ilmu hadits. Sehingga keilmuan beliau terkait kedua ilmu tersebut tidak diragukan lagi. (Mubarok 2000). Selama di Makkah Imam Syafi'i mendapatkan pendidikannya di Masjidil haram dari guru-gurunya, di samping belajar ilmu fiqh dan Ilmu Hadits beliau juga belajar al-Quran yang meliputi tilawah, tajwid dan tafsirnya. Di samping belajar juga Imam Syafi'i Kecil sangat tekun dalam menghafal Al-Quran, sehingga karena kesungguhan dan ketekunannya tersebut, ketika usianya menginjak sembilan tahun beliau telah menjadi seorang penghapal Al-Qur'an dan dan penghafal hadits (Rohidin 2004). Di masjid al-Haram inilah dia pernah belajar hadis dan Fiqh kepada Muslim ibn Khalid (w. 180 H), belajar ilmu Qur'an kepada Sufyan ibn 'Uyainah, dan Isma'il ibn Qasthantin, juga pernah belajar kepada Al-Lais ibn Sa'ad seorang Mujtahid Mesir, ahli Fiqh dan Ahli sastra Bahasa. (Mulyosari, tt).

Kemudian, atas saran salah satu gurunya ketika di Makkah Imam Syafi'i menghapal syari-syair kuno yang yang sezaman dengan masa turunnya al Qur'an dan memperdalam ilmu-ilmu yang berkaitan dengan bahasa Arab, seperti balaghah, dan cabang-cabang sastra Arab lainnya. Yang kelak oleh Imam Syafi'i 
Amrullah Hayatudin

ilmu-ilmu tersebut digunakan dengan baik sebagai alat dalam memahami isi kandungan Al Qur'an dan hadits dari segi bahasa (Al-Syarqawi 1981).

Sebagaimana sudah dijelaskan di atas bahwa Imam Syafi'i di samping sebagai penghapal Al Qur'an beliau juga merupakan penghafal hadits, kitab hadits yang beliau hafal adal karya ulama besar Imam Malik, yaitu Kitab al-Muwatha', Imam Syafi'i Belajar Al Muwatha' Imam Malik, dari seorang ulama yang bernama Sufyan bin 'Uyainah. Mendengar kehebatan Imam Malik sebagai seorang penulis Kitab Hadits yang sudah dihapalkannya tersebut. Pada usia dua puluh tahun, atas restu ibunda tercinta dan Surat pengantar dari Walikota Makkah, Imam Syafi'i meninggalkan kota Makkah pergi ke Madinah untuk berguru langsung kepada Imam Malik, dan selama di Madiah inilah Imam Syafi'i Belajar Hadits terutama kitab Al Muwatha' kepada Imam Malik ulama besar, penulis kitab Hadits yang seluruh isinya sudah dihapalkan olehnya (Zahroh, $\mathrm{tt}$ ).

Selama tinggal di Madinah kebutuhan hidupnya ditanggung oleh Imam Malik, Imam Syafi'i tidak selalu bersama dengan gurunya Imam Malik karena, Imam Syafi'i sering berkunjung ke daerah-daerah dalam rangka belajar adat istidat dan kebiasaan masyarakat di daerah tersebut. Meskipun demikian Tujuan pokok beliau ke Madinah yaitu belajar hadist yang selama ini dia hafal, dari penulis kitab haditsnya langsung yaitu Imam Malik sudah ditunaikannya dengan baik, bahkan hanya dalam waktu singkat saja beliau sudah memahami seluruh isinya (Zahroh, $\mathrm{tt})$.

Setelah selesai belajar dari Imam Malik di Madinah, Imam Syafi'i melanjutkan pendidikannya ke Irak, dan kepergiannya ke Irak merupakan saran dari Gurunya Imam Malik. Imam Syafi'i pergi ke Irak untuk belajar ilmu fiqh dari pewaris fiqh Imam Hanafi, yaitu dari Muhammad bin Hasan dan Abu Yusuf, yang terkenal dengan paham rasionalnya. Dan hanya dalam waktu dua tahun Imam Syafi'i mampu menguasai berbagai metode diskusi, metode istinbath hukum dan berbagai hal terkait dengan fiqh aliran Hanafiyah (Zahroh, tt). Sehingga apabila ada orang yang mengkritik akan fiqh nya Imam Hanafi, Imam Syafi'i akan meluruskan dan membelanya dengan mengatakan, bahwa setiap orang yang akan belajar Ilmu Fiqh dia harus tahu fiqh nya Imam Hanafi, karena keberadaannya tidak bisa dilepaskan dari perkembangan ilmu fiqh.

Selesai pengembaraanya di Irak dan belajar banyak terkait dengan fiqh Imam Hanafi, dengan penuh rasa hormat Imam Syafi'i kembali lagi ke Madinah. 
Telaah Istinbath Hukum Imam Syafi'i Tentang Kadar Susuan Yang Mengharamkan Pernikahan

Dan ikut membantu Imam Malik dalam mengajarkan Kitab Al Muwatha' kepada muridnya-murdinya. Sepulangnya dari Irak, al-Syafi'i dalam pembelajaran fiqhnya menggunakan metode baru yang belum pernah dilakukan oleh Imam Malik, metode tersebut adalah metode diskusi dan adu argumentasi (Rohidin 2004).

Berdasarkan pemaparan di atas, bisa diambil simpulan bahwa Imam Syafi'i merupakan salah satu murid Imam Malik dan juga Imam Hanafi, meskipun Imam Syafi'i dalam hal berguru kepada Imam Hanafi tidak secara langsung, tetapi beliau berguru melalui beberapa pewaris Ilmu Imam Hanafi yaitu Muhammad ibn Hasan dan Abu Yusuf.lainnya.

\section{Metodologi Istinbath Hukum Imam Syafi'i tentang Kadar Susuan yang Mengharamkan Pernikahan}

Ulama dalam menentukan suatu hokum terkait permasalah yang dihadapi selalu mengembalikannya kepada Al Qur'an sebagai sumber hokum yang pertama di dalam Hukum Islam. Namun, Rasulullah Saw, pada masanya pernah membolehkan para sahabat untuk berijtihad, hal ini sebagaimana yang diungkapkan beliau dalam hadits berikut ini:

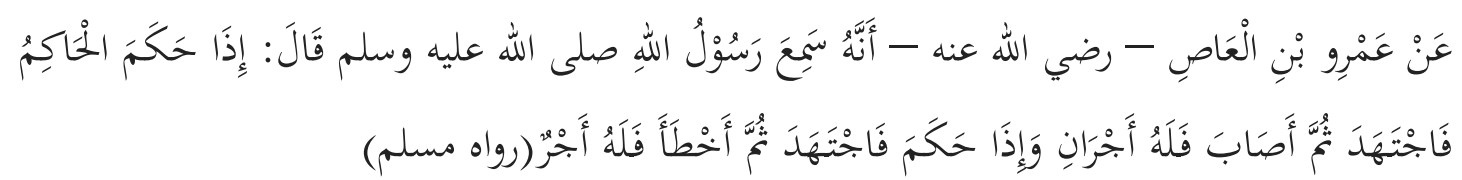

"Dari Amr bin Ash bahwa ia mendengar Rasulullah Saw. bersabda, "Apabila seorang hakim hendak memutuskan hukum, lalu berijtihad, kemudian benar, ia mendapatkan dua pahala. Jika ia hendak memutuskan hukum, lalu berijtihad kemudian ternyata salah, ia dapat satu pahala." (HR. Muslim) (Ismail al Bukhari 1987).

Hadits tersebut di atas kemudian dijadikan landasan oleh ahli ushul untuk mengembangkan berbagai metodologi istinbath Hukum dalam Islam (Azhari 2015). Kata istinbath secara bahasa berasal dari kata استنبط (istanbatha) yang mengandung arti menemukan, mengeluarkan (Sabiq 2010). Istinbath merupakan sebuah cara yang digunakan para mujtahid dalam pengambilan hukum dari sumbernya (al qur'an dan sunnah) (A. Mas'adi 1998). Sementara menurut hayatudin sebagaimana dalam bukunya ushul fiqh yang mengutif pendapatnya al fayumi menjelaskan bahwa istinbath adalah upaya menarik hukum dan alqur'an dan sunnah dengan jalan ijtihad (A. Mas'adi 1998). Jadi istinbath ialah pedoman 
Amrullah Hayatudin

bagi orang yang mau melakukan penggalian hukum dari dalilnya. Maka, untuk menentukan hukum seorang hakim harus mengetahui prosedur dan metodologi penetapan hokum dalam Islam (thuruq al istinbath) (Vani 2016).

Imam Syafi'i dalam menentukan Hukumnya, beliau mempunyai metode dan prosedur tersendiri yaitu, adapun prosedurnya adalah sebagai berikut: "Hukum asal adalah al-Qur'an dan Sunnah; apabila tidak ditemukan di dalam al-Qur"an dan Sunnah maka, menggunakan Qiyas (analogi) terhadap al Qur'an atau Sunnah (Lara 2017). Prosedur Istinbath Hukum Imam Syafi'i tersebut ini sebagaimana yang diungkapkan beliau dalam kitabnya, ar-Risalah sebagai berikut:

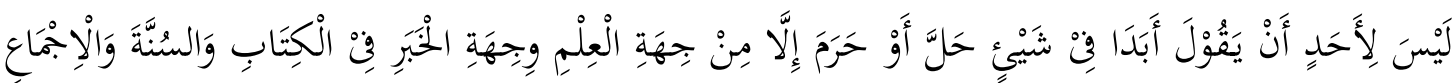

$$
\begin{aligned}
& \text { وَالْقِيَاسِ }
\end{aligned}
$$

"Tidak boleh seorang mengatakan dalam hukum selamanya ini, halah atau haram kecuali ada pengetahuan tentang itu, pengetahuan itu adalah kitab suci, qur'an, sunnah, 'ijma' dan qiyas" (Yanggo 1997).

Metode istinbath Imam Syafi'i secara garis besar dapat dilihat dari kitab alUmm, sebagaimana yang dikutip oleh Ali Hasan, sebagai berikut: "ilmu itu bertingkat secara berurutan pertama-tama adalah al-Qur'an dan as-Sunnah apabila telah tetap, kemudian kedua Ijma' ketika tidak ada dalam al-Qur'an an as-Sunnah dan ketiga Sahabat Nabi (fatwa sahabi) dan kami tahu dalam fatwa tersebut tidak adanya ikhtilaf di antara mereka, keempat ikhtilah sahabat Nabi, kelima qiyas yang tidak diqiyaskan selain kepada al-Qur'an dan as-Sunnah karena hal itu telah berada di dalam kedua sumber, sesungghunya mengambil ilmu dari yang teratas" (Hasan 2002)

Imam Syafi'i menempatkan Al Qur'an dan hadits mutawatir pada martabat pertama. Dan alasan Imam Syafi'i menempatkan hadits mutawatir sama dengan Al Qur'an dalam penentuan hukum karena menurutnya, sunnah mutawatir berfungsi menjelaskan al Qur'an, hal ini tentu berbeda dengan hadits ahad yang tidak bisa dianggap sebagai penjelas Al Qur'an. Disamping alasan di atas itu, Imam Syafi'i berpendapat bahwa al-Qur'an dan hadits keduanya merupakan wahyu, yang mana al qur'an merupakan wahyu matluwin sementara hadits merupakan wahyu ghairu matluwin, meskipun tentu kekuatan keduanya dalam argumentasi hokum tidak sama. (Yanggo 1997).

JAS: Volume 2 Nomor 1, 2020 
Telaah Istinbath Hukum Imam Syafi'i Tentang Kadar Susuan Yang Mengharamkan Pernikahan

Sementara, Ijma oleh Imam Syafi'i ditempatkan pada martabat kedua setelah al qur'an dan hadits, dan ijma' yang diakui pun adalah ijma' yang memiliki khasas. Kemudian Martabat yang ketiga setelah al qur'an, hadits dan Ijma' adalah qoul shahabat. Dan yang terakhir prosedur yang digunakan Imam Syafi'i adalah Qiyas (Analogy)

1. Al-Qur'an.

Imam al-Syafi'i dalam menetapkan hukum berdasarkan al-Qur'an merupakan hujjah syara' yang paling qath'i dalam menetapkan hukum. Beliau memandang al-Qur'an dan al-Hadits dalam satu martabat, bahkan hanya pada keduanyalah sumber hukum Islam. Sumber hukum yang lainnya dipautkan kepadanya. Beliau menetapkan al-Hadits sederajat atau sejajar dengan al-Qur'an ketika melakukan istinbath (penggalian hukum), bukan berarti menganggap bahwa sunnah juga mempunyai kekuatan argumentasi hukum yang sama dalam penetapan hukum islam.

Beliau Juga memposisikan bahwa al-Hadits dengan al-Qur'an itu sama dalam hal mengeluarkan hukum-hukum cabang ( $f u r u^{\prime}$ ), dengan demikian bisa diambil simpulan bahwa dalam pandangan Imam Syafi'i terkait dengan sumber hukum, hadits bukanlah cabang dari al-Qur'an. Oleh karena itu, apabila terdapat perselisihan antara hadits dengan al-Qur'an maka hendaklah yang didahulukan adalah hukum dari al-Qur'an (Al-Shiddiqie 1997).

Dalam istinbath hukumnya Imam al-Syafi'i memahami al-Qur'an menurut lahiriah (dzahir) ayat, kecuali jika ada qarinah-qarinah lain yang menunjukan bahwa yang harus digunakan atau dituruti bukanlah makna dzahir ayat tersebut. Dalam hal urutan mujtahid, Imam al-Syafi'i merupakan salah satu mujtahid yang tergolong dalam Mujtahid Mutlak Musytaqil, sebagaimana Imam Hanafi, Imam Malik atau imam Hanbali, sebab mereka langsung mengungkapkan dan menggali hukum yang pokok, yaitu al-Qur'an.

2. Al-Sunnah.

Al-Sunnah merupakan dasar hukum yang kedua setelah al-Qur'an seluruh kaum muslimin telah sepakat bahwa sunnah yang dimaksud sebagai aturan dan pedoman hidup umat manusia adalah sunnah mutawatir yang sampai kepada kita dengan sanad yang shahih, sehingga kita mempunyai keyakinan dalam hati bahwa, yang sampai kepada kita tersebut adalah benar datangnya dari Rasulullah Saw. Dan bisa dijadikan sebagai hujjah syari'yah, tempat para mujtahid mengeluarkan hukum-hukum syara'(Faturahman 1997) 
Amrullah Hayatudin

Imam al-Syafi'i menjadikan sunnah sebagai hujjah syara' yang kedua setelah al-Qur'an. Dan belai juga menegaskan bahwa hadits ahad adalah hujjah. Akan tetapi meskipun Imam al-Syafi'i menggunakan hadits ahad dalam menentukan hukum, beliau tidak menempatkan hadits ahad sejajar dengan Al Qur'an atau hadits mutawatir. Karena menurutnya, Hadits Ahad bersifat Dzanni Dilalah sementara Al Qur'an dan hadits mutawatir bersifat Qathi Dilallah dan juga Qathi Tsubut-nya (Al-Shiddiqie 1997).

Imam al-Syafi'i dalam al-Risalah mengemukakan sejumlah hujjah untuk membuktikan bahwasanya al-Sunnah adalah suatu hujjah yang kuat dalam hal-hal hokum agama. Dan beliau telah berjasa dalam melakukan kodifikasi dalil-dalil yang mendukug terkait dengan bahwa al-Sunnah merupakan dalil hukum dalam hukum Islam. Oleh sebab itu beliau mendapat julukan sebagai "Nashirus Sunnah" (penolong sunnah) (Al-Shiddiqie 1997).

Di samping hal tersebut di atas, menurut Musthafa al-Siba'iy sebagaimana dikutip Huzaemah Tahido Yanggo (1997), sebab lain yang menjadikan Imam alSyafi'i dijuluki Nashir al-Sunnah (penolong sunnah). Adalah bahwa Imam al-Syafi'i merupakan peletak batu pertama terkait dengan kaidah periwayatan hadits, dan bahkan beliau juga merupakan orang yang teguh mempertahankan sunnah melebihi dari Imam Malik sebagai gurunya dalam ilmu hadits. Dalam hal penggunaan hadits sebagai sumber dalam menentukan hukum Imam Syafi'i berbeda dengan guru-gurunya, termasuk dalam hal ini berbeda dengan Imam Malik dan Imam Hanafi. Menurutnya jika sebuah hadits itu shahih dan mutasil sanad hingga kepada Rasulullah Saw, maka hadits tersebut wajib untuk diamalkam tanpa harus dibandingkan atau dikaitkan dengan Amal Ahlu Madinah. Hal ini berbeda dengan apa yang dilakukan Imam Malik, yang mana menurutnya hadits tersebut baru bisa diterima apabila popular dilakukan oleh orang-orang madinah (Ahlu al Madinah). Dan dalam hal menerimaan hadits Imam Syafi'i tidak mensyaratkan syarat yang banyak untuk bisa menerima hadits, hal ini berbeda dengan apa yang dilakukan oleh Imam Hanafi.

Adapun fungi hadits bagi Al Qur'an adalah untuk memberikan kejelasan makna yang diinginkan oleh wahyu (Al Qur'an), di samping itu juga untuk memberikan kejelasan hukum, apakah yang dimaksudkan oleh Al Qur'an itu larangan atau perintah. Di samping itu juga Hadits berfungsi untuk merinci atau mengkhususkan yang sifatnya umum dalam Al Qur'an (Faturahman 1997).

JAS: Volume 2 Nomor 1, 2020 
Telaah Istinbath Hukum Imam Syafi'i Tentang Kadar Susuan Yang Mengharamkan Pernikahan

Terkait dengan fungsi hadits tehadap al qur'an sebagai penjelas Imam alSyafi'i dan sebagaian ulama ahli atsar yang berpendapat bahwa fungsi hadits sebagai penjelas Al Qur'an terbagi ke dalam lima bagian:

a. Bayān at Tafsil, yaitu berfungsi menjelaskan ayat-ayat mujmal (yang bersifat Global atau Umum).

b. Bayān Takhsīs, adalah berfungsi menentukan sesuatu (mengkususkan) ayat-ayat yang bersifat umum.

c. Bayān Ta'yien, Adalah Fungsi hadits Sebagai penentu terhadap sesuatu mana yang hakikatnya dimaksud oleh ayat tersebut.

d. Bayān Naskh, yaitu menentukan mana ayat-ayat yang sudah yang dimansukh dan mana ayat sebagai nasikh dari ayat-ayat al-Qur'an yang kelihatan bertentangan.

e. Bayān Tasyri', yaitu menetapkan suatu hukum yang tidak ada dalam alQur'an (Al-Shiddiqie 1997).

3. Al-Ijma'

Ijma' merupakan metode istinbath hukum yang ketiga yang digunakan oleh Imam al-Syafi'i setelah al-Qur'an dan al-Hadits. Definisi Ijma' secara Bahasa adalah kebulatan tekad terhadap suatu persoalan (Hayatudin 2019). Sementara, secara istilah Ijma' ialah Konsensus atau kesepakatan ulama Mujtahid dari golongan umat Islam tentang hukum Islam dalam kasus tertentu, pada suatu masa setelah Rasulullah Saw wafat (Djazuli 2000).

Sedangkan pengertian Ijma' menurut al-Ghazali:

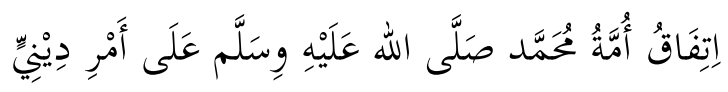

"Kesepakatan ummat Muhammad SAW, atas suatu perkara yang berhubungan dengan urusan agama".

Dalam pandangan Imam al-Syafi'i, ijma' merupakan hujjah syara' dan menempatkannya setelah al-Qur'an dan al-hadits sebelum qiyas. Artinya bahwa ijma' harus didahulukan daripada qiyas serta harus diakhirkan ijma' dari daripada beristidlal dengan menggunakan Al-Qur'an dan Al-Hadits (Al-Shiddiqie 1997).

Dan terkait dengan definisi Ijma' Imam al-Syafi'i berpendapat bahwa Ijma' merupakan kesepakatan para mujtahidin semasanya tentang hukum tertentu, sebagaimana yang diungkapkan beliau dalam kitab ushul fiqhnya ar-Risalah: 


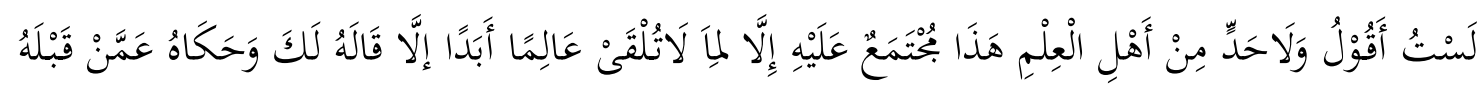

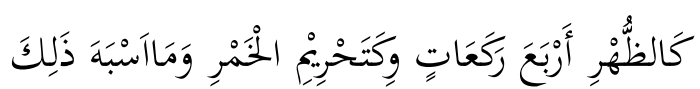

"Tidaklah aku katakan dan tidak pula seseorang dari ahli ilmu: "ini sudah diijma'kan, melainkan bagi apa yang engkau tidak menentukan seseorang alim melainkan mengatakannya kepada engkau. Dan diceritakannya dari orang sebelumnya, seperti dzuhur empat rakaat, seperti haram arak, dan yang serupanya"(Djazuli 2000).

Ijma yang mula-mula mendapat itibar Imam al-Syafi'i adalah ijma sahabat dan beliau menerima ijma sebagai hujjah syara' di tempat yang tidak ada nash. Beliau berhujjah untuk menetapkan dasar ijma, dari ucapan umar bin khattab di Jabiah, ia berkata:

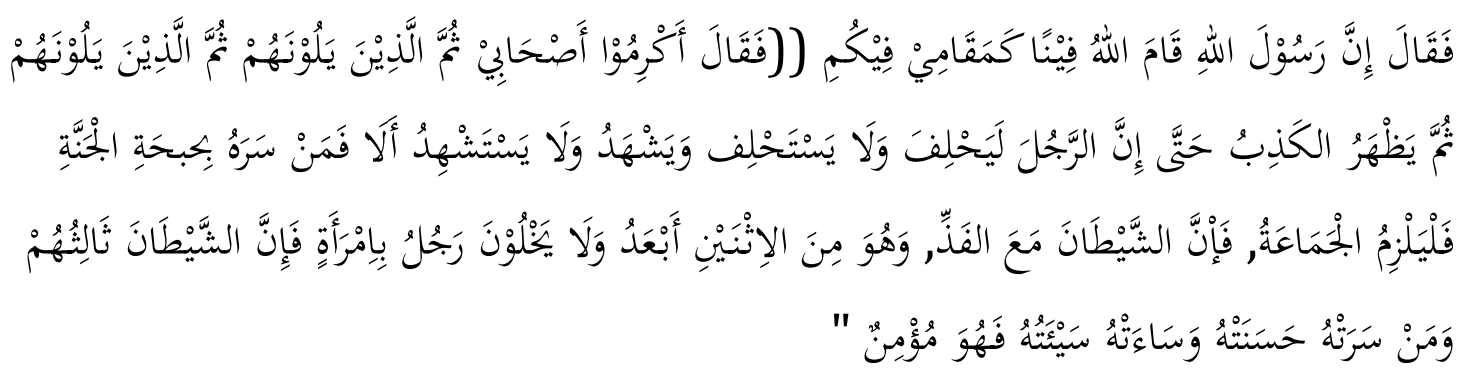

“Sesungguhnya Rasulullah telah berdiri dihadapan kami sebagaimana aku dihadapanmu, maka Rasulullah berkata: "muliakanlah sahabat-sahabatku, kemudian orang-orang yang mengiringi mereka kemudain berkembanglah dusta orang yang bersumpah padahal ia tidak diminta bersumpah, dan dia menjadi saksi padahal ia tidak diminta menjadi saksi. Ketahuilah barang siapa yang tidak disenangkan hatinya oleh kesedapan surga, maka tetaplah dia bersama jamaah karena sesungguhnya syetan itu bersama orang yang sendiri dan ia tidak jauh dari orang kedua. Dan janganlah berhalwat seorang lelaki dengan seorang perempuan karena syetan akan menjadi orang ketiga dan barang siapa dapat disenangkan kebijaksanaan dan disusahkan hatinya oleh kejahatannya maka itulah orang mukmin (Al-Shiddiqie 1997).

Dengan demikian, maka ijma yang dapat diterima sebagai hujjah syara' adalah ijma seluruh ulama dari segenap penjuru dunia Islam. Imam al-Syafi'i berpendapat bahwa kesepakatan ulama-ulama Madinah terkait hukum tertentu 
Telaah Istinbath Hukum Imam Syafi'i Tentang Kadar Susuan Yang Mengharamkan Pernikahan

bukanlah Ijma' yang bisa dijadikan argumentasi hukum (hujjah) dalam menentukan hukum dalam Islam.

4. Qiyas

Merupakan metode ijtihad yang digunakan oleh Imam al-Syafi'i dalam menetapkan hukum, dan ditempatkan setelah ijma. Dengan demikian dalam pandangan Imam al-Syafi'i, qiyas dapat dijadikan sebagai hujjah syara', tatkala tidak ditemukan dalam al-Qur'an, dalam al-Hadits serta ijma atas kasus yang memerlukan penetapan hukum.

Menurut al-Ghazāli sebagaimana dikutip oleh Syarifuddin Al Ghazāli berpendapat dalam kitab al-Mustasfa, bahwa qiyas adalah membandingkan sesuatu yang sudah ada ketentuan hukumnya kepada sesuatu yang belum ada ketentuan hukumnya, dalam hal menetapkan hukum. Dengan cara menetapkan satu hukum kepada hukum yang lainnya, atau meniadakan hukum dari keduanya. Karena ada kesamaan illat (alasan hokum) antara keduanya (Syarifuddin 1997).

Ijtihad menurut Imam al-Syafi'i dalam hal tidak dinashkan hanyalah dengan qiyas. Oleh karena itu, Imam al-Syafi'i menetapkan bahwa qiyas itu adalah ijtihad. Dan qiyas dalam pandangan beliau sebagaimana nampak dalam contoh-contohnya yang banyak telah beliau buat. Qiyas menurutnya sesuai dengan pengertian ulama ushul yaitu:

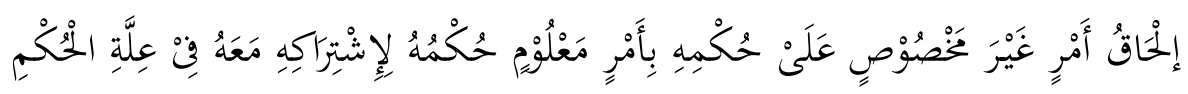

"Menghubungkan suatu urusan yang tidak dinashkan hukumnya dengan suatu urusan yang diketahui hukumnya kerena bersekutu dalam illat hukum" (Zahroh, $\mathrm{tt}$ ).

Dalam menetapkan hukum Imam al-Syafi'i menggunakan qiyas sebagai dasar dari dasar-dasar keislaman untuk mengetahui sesuatu yang ditunjukan oleh al-Qur'an dan al-Sunnah dari hukum-hukum yang tidak ada nash-nya yang jelas. Kemudian beliau tidak membenarkan ijtihad dengan ra'yu yakni istihsan atau dengan yang lainnya.

Berdasarkan metode-metode istinbath hukum di atas, maka dalam menetapkan kadar susuan yang mengharamkan nikah, Imam al-Syafi'i berpendapat bahwa susuan yang berakibat terhadap haramnya seseorang untuk

JAS: Volume 2 Nomor 1, 2020 
Amrullah Hayatudin

melakukan pernikahan karena bersatus hukum saudara sepersusuan adalah lima kali susuan.

Imam Syafi'i dalam melakukan istinbath hukum mengenai kadar susuan yang mengakibatkan sesorang menjadi saudara sepersusuan sehingga haram untuk melakukan pernikahan. Pertama-tama beliau mencari dalam al-Qur'an, dan ternyata di dalam al-Qur'an tepatnya dalam QS. al-Nissa ayat 23 sebagaimana kutipan berikut:

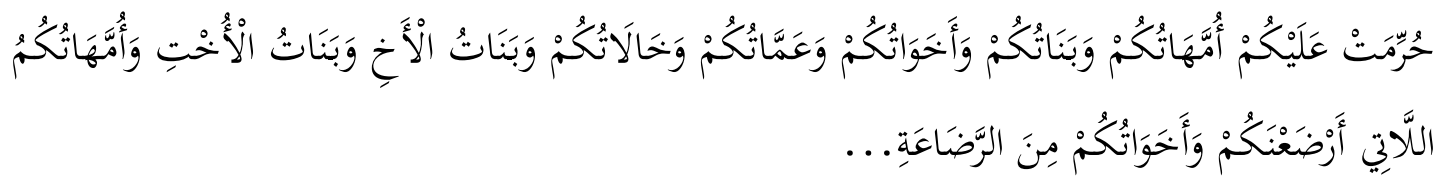

"Diharamkan atas kamu (mengawini) ibu-ibumu; anak-anakmu yang perempuan; saudara-saudaramu yang perempuan, Saudara-saudara bapakmu yang perempuan; Saudara-saudara ibumu yang perempuan; anak-anak perempuan dari saudara-saudaramu yang laki-laki; anak-anak perempuan dari saudarasaudaramu yang perempuan; ibu-ibumu yang menyusui kamu; saudara perempuan sepersusuan..."(QS. Annisa [3]: 23)(Departemen Agama 2010)

Apabila diperhatikan dalam ayat tidak disebutkan secara rinci kadar susuan yang menyebabkan terjadinya pengharaman nikah. Dikarenakan Imam Al-Syafi'i dalam menggunakan al-Qur'an sebagai sumber dalam menetapkan hukum, Imam Syafi'i memahami al Qur'an menurut dzahir ayat, kecuali jika ada qarinah-qarinah lain yang bisa menjadi alasan untuk memalingkan dari makna dzahir ayat kepada makna yang lain.

Berdasarkan QS. al-Nissa ayat 23 di atas, menurut Imam Syafi'i terdapat qarinah lain, yang menunjukkan bahwa bukan arti lahir yang harus dipakai atau dituruti. Jadi menurut analisis penulis bahwa Imam Syafi'i menganggap bahwa surat al-Nissa ayat 23 di atas, masih berbentuk umum. Dan oleh karena hal tersebut Imam Syafi'i menganggap bahwa fungsi hadits terhadap al-Qur'an salah satunya adalah Bayān Takhsīs, yaitu menentukan sesuatu dari ayat umum, maka dengan begitu Imam al-Syafi'i mencarinya dalam al-Hadits dan beliau menggunakan hadits di antaranya yaitu hadits riwayat Aisyah Ra yang berbunyi:

JAS: Volume 2 Nomor 1, 2020 


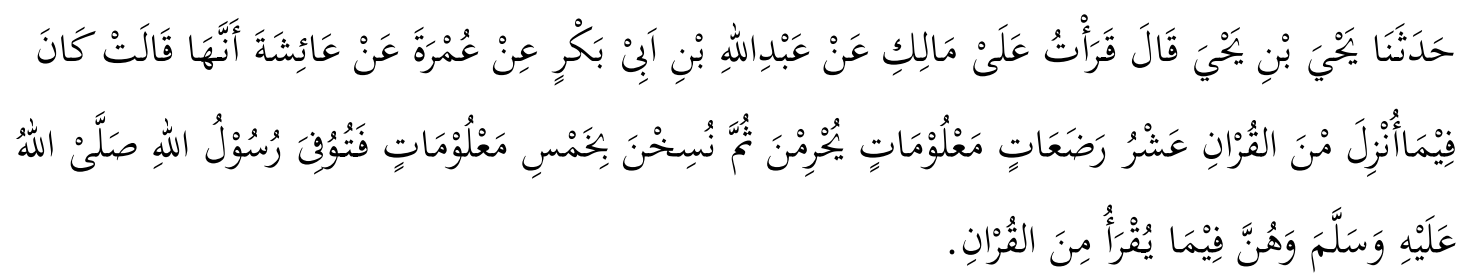

"Berkata kepada saya Yahya ibn Yahya aku telah membaca dari Malik ibn Abdullah ibn Abu Bakar dari Urwah dari Aisyah beliau berkata:"Sebagian dari kandungan al-Qur'an yang diturunkan adalah sepuluh kali susuan yang diketahui. Kemudian ketentuan itu dinasakh menjadi lima kali suusan yang diketahui. Kemudian Rasulullah SAW wafat, sedangkan kata-kata tersebut termasuk di dalam al-Qur'an yang dibaca" (Al Syafii, tt)

Dan juga hadits lain yang juga riwayat Aisyah yang berbunyi:

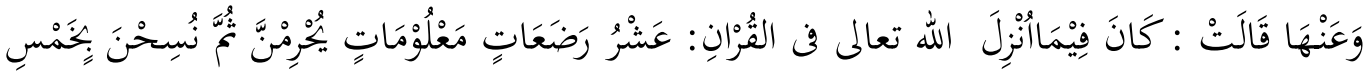

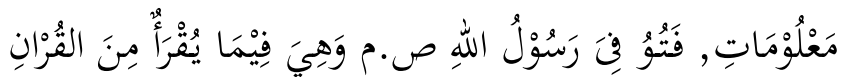

"Dan daripadanya. Ia berkata: "Sepuluh penyusuan yang ma'lum mengharamkan" itu adalah dari ayat-ayat Qur'an yang diturunkan, kemuduan dimansukh-kan dengan lima (penyusuan) yang ma'lum: maka Rasulullah SAW wafat keadaan ayat itu dibaca sebagai Qur'an" (Al Syafii, tt)

Dengan begitu maka Imam al-Syafi'i berpendapat bahwa satu susuan, atau dua kali susuan tidak menyebabkan pengharaman nikah, menurut beliau yang menjadikan sebab haramnya pernikahan adalah lima kali susuan yang terputusputus. Hal ini sebagaimana pendapat beliau dalam kitabnya al-Umm yang berbunyi:

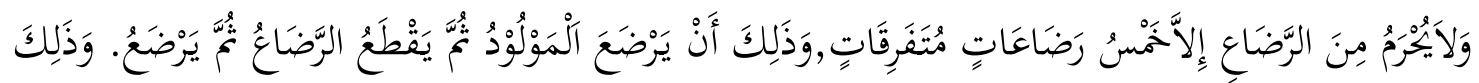

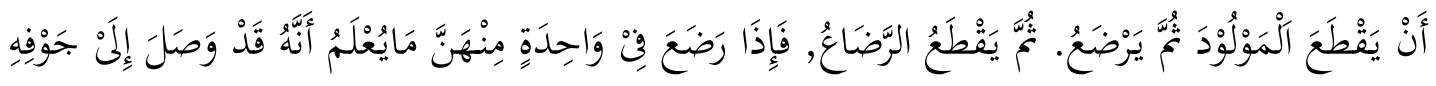

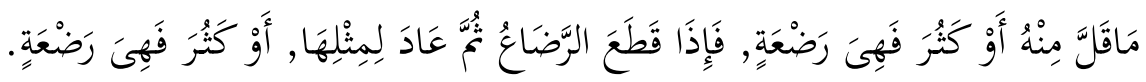

"Sepersusuan tidak mengharamkan nikah kecuali lima kali susuan yang terpisah-pisah, dan yang demikian itu apabila si bayi menyusu kemudian menyusu lagi, kemudian memutuskan lagi susuannya itu, maka apabila sibayi menyusu 
Amrullah Hayatudin

dalam satu akli susuan atau isapan dari lima kali yang terpisah-pisah yang tidak diketahui apakah sesungguhnya susuannya itu teleh ketenggorqaokan baik sedikit ataupun banyak maka dihitung satu kali susuan, dan apabila si bayi itu memutuskan susuan kemudian menyusu lagi seperti semula atau lebih banyak maka dihitung satu susuan" (Al Syafii, $\mathrm{tt}$ )

Dengan begitu dalam menentukan hukum tentang kadar susuan, yang menjadikan status seseorang menjadi saudara sepersusuan sehingga mengharamkan pernikahan. Imam al-Syafi'i menggunakan dua metode istibath hukum yaitu dengan al-Quran dan al-Sunnah. Yang mana beliau pertama-tama mencari hukum kadar susuan dalam al-Qur'an kemudian beliau menemukan hukum kadar susuan dalam surat al-Nissa ayat: 23 tetapi ayat tersebut masih umum, dan beliau berpendapat bahwa ayat tersebut masih bisa ditakhsis dengan hadits riwayat Aisyah di atas.

Maka kesimpulan hukum dari Imam al-Syafi'i adalah bahwa satu susuan atau dua kali susuan tidak menjadikan sebab terjadinya hubungan nasab, tetapi lima kali susuan yang terputus-putuslah yang menjadikan sebab terjadinya hubungan nasab.as-Sunnah.

\section{A. Simpulan}

Imam Syafi'i dalam menentukan hukum tentang kadar susuan yang menjadaikan seseorang menjadi saudara sepersusuan, yang kemudian mengharamkan pernikahan menggunakan dua metode istibath hukum yaitu dengan al-Quran surat an Nisa ayat 23 dan al-Sunnah, (hadits Rasulullah Saw dari Aisyah). Yaitu pertama-tama mencari hukum kadar susuan dalam al-Qur'an surat al-nissa ayat: 23 tetapi ayat tersebut masih umum, Imam Syafi'i berpendapat bahwa ayat tersebut masih bisa ditakhsis dengan hadits riwayat Aisyah. Maka kesimpulan hukum dari Imam al-Syafi'i adalah kadar susuan yang mengharapkan pernikahan adalah lima kali susuan yang terputus-putus.

\section{Daftar Rujukan}

\section{A. Mas'adi, Ghufron. 1998. Pemikiran Fazlur Rahman tentang Metodologi Pembaharuan Hukum Islam. Jakarta: Raja Grafindo Persada.}

Al-Shiddiqie, Hasbi. 1997. Pokok-pokok Fiqih Islam. Jakarta: Bulan Bintang. JAS: Volume 2 Nomor 1, 2020 
Telaah Istinbath Hukum Imam Syafi'i Tentang Kadar Susuan Yang Mengharamkan Pernikahan

Al-Syarqawi, Abdurrahman. 1981. Aimmah al-Figh al-Tis'ah. Beirut: Dar Iqra.

Azhari, Fathurrahman. 2015. "Metode Istinbath Hukum Ibn Rusyd Dalam Kitab Bidayah al-Mujtahid." Tashwir 3(8): 351-74.

Departemen Agama. 2010. Al Qur'an Tajwid dan Terjemahnya. Bandung: CV. Dipenogoro.

Djazuli, A. 2000. Ushul Fiqh, Metodologi Hukum Islam. Jakarta: PT. Raja Grafindo Persada.

Faturahman, Muhtar Yahya dan. 1997. Dasar-dasar Pembinaan Fiqh Islam. Bandung: PT. Al Maarif.

Habibullah, Eka Sakti. 2017. "Pandangan Imam Abu Hanifah dan Imam Syafi'i tentang Al-Istihsan." Al Mashlahah Jurnal Hukum dan Pranata Sosial Islam 4(07): 451-66.

Hasan, Ali Hasan. 2002. Perbandingan Mazhab. Jakarta: PT. Grafindo Persada. Hayatudin, Amrullah. 2018. "Istinbath Hukum Imam Malik Ibn Anas Tentang Kadar Susuan Yang Mengharamkan Pernikahan." TAHKIM, Jurnal Peradaban dan Hukum Islam 1(2): 23-39.

———. 2019. Uhsul Fiqh; Jalan Tengah Memamahami Islam. Jakarta: Amzah.

Hidayat, Rahmat. 2018. "Pemikiran Pendidikan Islam Imam As - Syafi ' i dan Implikasinya Terhadap Pendidikan Islam di Indonesia." Almufida III(01): 10731.

Ismail al Bukhari, Muhammad. 1987. Shahih Bukhari. Beirut: Dar Ibn Katsir al Yamamah.

Lara, Lailiyah Buang. 2017. "Metode Istinbath Hukum Imam Syafi ' i : Telaah atas Konsep Kadar Nafkah Istri." IN RIGHT; Jurnal Agama dan Hak Azazi Manusia 6(2): 266-92.

Mubarok, Jaih. 2000. Sejarah dan Perkembangan Hukum Islam. Bandung: PT. Remaja Rosdakarya.

Mughniyah, Muhammad Jawad. 1996. Fiqih Lima Madzhab. Jakarta: PT. Lentera Basritama.

Mulyosari, Endah Trie. "Perjalanan Pemikiran Hukum asy-Syafi'i." : 251-66.

Muslim, Imam Abi Husain. 2010. Shahih Muslim. Mansura: Maktabah Fayadh li Thabaati wa Nasr.

JAS: Volume 2 Nomor 1, 2020 
Amrullah Hayatudin

Ningrum, Ita Sofia. 2017. "Dasar-Dasar Para Ulama Dalam Berijtihad dan (Fundamentals of Scholars in Conducting ijtihad and Istinbāţh Methods of Law)." Mizan: Jurnal Ilmu Syariah 5(1): 93-108.

Rohidin, Rohidin. 2004. "Historisitas Pemikiran Hukum Imam Asy-Syafi'i." Jurnal Hukum IUS QUIA IUSTUM 11(27): 97-105.

Rohmah, Anny Nailatur, dan Ashif Az Zafi. 2020. “Jejak Eksistensi Mazhab Syafi `i di Indonesia." Tamaddun: Jurnal Sejarah dan Kebudayaan Islam 8(1).

Sabiq, Sayyid. 2010. Fikih Sunnah. Jakarta: Pena Pundi Aksara.

Sari, Fitri. “Anak Susuan Dalam Hadis Nabi dan Pandangan Ulama.” : 309-42.

Al Syafii, Abdullah Ibn Idris. Al Umm. Beirut: Dar al-Fikr.

Syarifuddin, Amir. 1997. Ushul Fiqih II. Jakarta: Logos.

Vani, Elrika. 2016. "Studi Analisis Metode Istinbath Hukum Imam Hanafi dan Imam Syafii tentang Wali Mujbir.” Skripsi: 1-129.

Yanggo, Huzaimah Tahido. 1997. Pengantar Perbandingan Madzhab. Jakarta: Logos.

Zahroh, Abu. Tarikh al-Mazahib al-lslamiyah. Kairo: Dar al-Fikr al- ' Arabi.

JAS: Volume 2 Nomor 1, 2020 